Review Paper UDC 78.01:7.011

doi: $10.21464 / \mathrm{sp} 311019$

Received December $8^{\text {th }}, 2014$

\begin{abstract}
$\underline{\text { Maja Bjelica }}$
University of Primorska, Science and Research Centre Koper, Institute for Philosophical Studies,

Garibaldijeva 1, SI-6000 Koper

maja.bjelica@zrs-kp.si
\end{abstract}

\title{
Musically Human-Made World
}

\section{Possibilities for Recomposing and Creating a Human World Through the Activity of Music}

\begin{abstract}
This paper offers an interdisciplinary account and a reflection of the interconnections and relations among music, human life, and the world. With the intention to present the possible ways of defining music, two approaches are examined. These approaches are "musicking" and the disjunctive strategy of understanding music, both of which provide a descriptive and not an evaluative account. After a brief acknowledgement of music as a means for political propaganda, and as a means belonging to the sphere of mass production and conformism, the other side of music is to be presented mainly through the concept of "community music", where the unconditional welcome of striving towards the impossible and the infinite responsibility towards the other makes music universal exercise in ethical gestures, openness, and acceptance.
\end{abstract}

\section{Keywords}

music, music and philosophy, definition of music, music as event, "musicking", musical encounter, propaganda music, "community music", unconditional welcome

The purpose of this paper is to show, on the basis of various examples, possible wide interconnections and relations between music and creation of world(s), culture(s), society, nationality(ies), community(ies), and one's own relation towards the other in general. In order to do that, it seems reasonable to look into the understanding of the notion of music, its definitions, and explanations.

While trying to define what music is, we might come to a slippery ground since there is no mutual agreement about it. Looking at some statements and definitions about music, we might see that musicians, philosophers, and other scholars or artists approach the phenomenon of music in different ways. John Blacking, one of the most prominent ethnomusicologists, said that music is a humanly organised sound. ${ }^{1}$ On the other hand, John Cage, the notorious avant-garde American composer, thought of music as sound in general. ${ }^{2}$ Many definitions describe music through its relation to language, or better, through their similarities and/or differences. There are myriad statements about music

John Blacking, How Musical is Man?, University of Washington Press, Seattle - London 2000, p. 10.
John Cage, Silence. Lectures and Writings by John Cage, Wesleyan University Press, Hanover 1961, p. 3. 
that emphasise a certain aspect of this omnipresent phenomenon and it would be impossible for us to take into account every single one of them. For now, let us consider a couple of recent accounts that approach defining music in an experiential and analytical way.

In the 1998 book entitled Musicking, ${ }^{3}$ the author Christopher Small introduced these two terms: 'to music', as a verb and 'musicking', as the present participle or gerund of this verb. He did so mainly because he finds defining the noun 'music' impossible due to the fact that the word 'music' is just an abstraction of the musical activity, "whose reality vanishes as soon as we examine it at all closely". ${ }^{4}$ In this regard, Small dared to say that "there is no such thing as music". Small said that our habit of thinking in abstractions is useful to a certain point, but it also has its dangers. One of the "wrongs" of defining abstract notion of music was, and still is, the neglect of the core musical activity - performance. This is why the author proposed the usage and definition of the musical terms in the form of the verb, namely 'to music' and 'musicking'.

"To music is to take part, in any capacity, in a musical performance, whether by performing, by listening, by rehearsing or practicing, by providing material for performance (what is called composing), or by dancing."

The author emphasised that this understanding of the term 'to music' pays special attention to musical performance and activity. Moreover, he stated, it is not a prescriptive, but merely a descriptive term. Small went even further in defining the term, especially in emphasizing the importance of the musical performance, activity and event or happening. In musicking

“... different activities add up to a single event, whose nature is affected by the ways in which all of them are carried out, and we have a tool by means of which we can begin to explore the meanings that the event as a whole is generating."7

The main characteristic of this event is that everybody who is performing these activities is involved, even the ticket sellers and the cleaning team after the happening, which can be quite problematic. While understanding musicking as an activity of everybody's involvement,

“... [w] begin to see a musical performance as an encounter between human beings that takes place through the medium of sounds organized in specific ways. Like all human encounters, it takes place in a physical and a social setting, and those, too, have to be taken into account when we ask what meanings are being generated by a performance." 8

Moreover, Small warned the reader that, in order to understand the activity or event of musicking, we should not be asking ourselves "what does it mean?", but rather "What is really going on here?" Small explained that his main purpose in the mentioned book was

“... to propose a framework for understanding all musicking as a human activity, to understand not just how but why taking part in a musical performance acts in such complex ways on our existence as individual, social and political beings." 10

Even before that, he stated that

“... [a]ny theory of musicking, which is to say any attempt to explain its meaning and its function in human life, that cannot be used to account for all human musicking, no matter how strange, primitive or even antipathetic it may seem to our perceptions, is not worth the paper it is written on." 11

Therefore, Small was looking for a theory that could be applied to any kind of musical activity. The author continued with the statement that all of us 
already have our own "theory of musicking", and that we just have to make it conscious and become aware of it in order to take control of our musical lives. The theory of musicking is

“... an important component of our understanding of ourselves and of our relationships with other people and the other creatures with which we share our planet. It is a political matter in the widest sense." 12

He explained this statement with the claim that

“... [t] he act of musicking establishes in the place where it is happening a set of relationships, and it is in those relationships that the meaning of the act lies." 13

And to this he added:

"The act of musicking in its totality, itself provides us with a language by means of which we can come to understand and articulate those relationships [of musical performance] and through them to understand the relationships of our lives." 14

In Small's theory of musicking, we can find various accounts that explain the understanding of music (even as an abstract matter) as an intersubjective space, where relationships emerge, and individuals might communicate through absolute attentive listening and mutual care. But still, we can identify some problematic claims or fallacies in his statements. At this point we could expose two of them: the first one is the question about the end of musicking. Where or when does musicking end, if we say that even cleaners are part of the activity? When does the musician stop being a musician, and starts being a mother? Moreover, are the people that were constructing the building of the concert hall also part of the same process of musicking? The second problem that emerges from his claim is the understanding of our relationships with other creatures with which we share our planet. How do we do it? Is he not saying that musicking is a human activity? How are these other creatures involved? I will not try to answer these questions for now, as at this point I would only like to point them out in order to show that even Small's theory of musicking does not answer all the questions that might arise when defining musical activity.

Similarly, in an article about defining music which appeared as the introductive chapter in the recently issued Routledge Companion to Philosophy and Music, ${ }^{15}$ Andrew Kania stated that due to the difficulties in defining the notion

Christopher Small, Musicking. The Meanings of Performing and Listening, Wesleyan University Press, Middletown 1998, pp. 1-18.

Ibid., p. 2.

5

Ibid.

Ibid., p. 9.

Ibid., p. 10

Ibid.

Ibid.
10

Ibid., p. 12.

11

Ibid., p. 11.

12

Ibid., p. 13.

13

Ibid.

14

Ibid., p. 14

15

Andrew Kania, "Definition", in: Theodore Gracyk, Andrew Kania (eds.), The Routledge Companion to Philosophy and Music, Routledge, London - New York 2014, pp. 3-13. doi: https://doi.org/10.4324/97802038 30376.ch1. 
of music, one should look for a descriptive definition, and not an evaluative one. In searching for the definition of music, Kania emphasised the centrality of the concept of musical event that helps in defining other musical notions. While talking about sound, he said that it is a necessary, but not a sufficient element for defining music. When talking about a musical sound, one could look into its intrinsic characteristics, its subjective perception from the listener's point of view, or even its intentionality of being produced or heard as music. An important aspect of music is also its temporal organisation. Since he could find some more examples of music that these definitions are not including, Kania adopted the so-called disjunctive strategy of defining music that provides an explanation for (almost) every example of musical phenomena. In this way he proposed the following definition:

"Music is (1) any event intentionally produced or organized (2) to be heard, and (3) either (a) to have some basic musical feature, such as pitch or rhythm, or (b) to be listened to for such features." 16

Based on these examples, we can conclude that defining music, whether by a noun or a verb, is a very complex activity. That is why at this point I would propose to agree for the purpose of the present discussion that music is a kind of human activity that involves sounds that are intentionally organised.

Let us now look into some examples of how music contributes to the creation of society and any other kind of human environment. When trying to present some positive aspects of music in establishing ethical relations among people, be it strangers, acquaintances or friends, it should also be taken into account that music does not always have exclusively positive characteristics. It might also be used for political or ideological propaganda, for controlling the masses, for developing conformism, etc. Let us list only a couple of examples of these uses of music.

One of the most thoroughly studied usages of music is the propaganda music of the totalitarian regimes of the $20^{\text {th }}$ century. Taking music in Nazi Germany as a study case, we can see that from the Nazi point of view, music had a unique significance and power to seduce and sway the masses. ${ }^{17}$ The Party made widespread use of music in its public appearances, and music featured prominently at rallies and other public events. Many propaganda songs were aimed at young people, and the Hitlerjugend (Hitler Youth) developed an elaborate music program. Music was seen as the great crowd-pleaser - as the Minister of Propaganda Joseph Goebbels put it,

“... [m] usic affects the heart and emotions more than the intellect. Where then could the heart of a nation beat stronger than in the huge masses, in which the heart of a nation has found its true home?"18

Already in 1933, when Adolf Hitler became Prime minister, all German radio stations were taken under control by Goebbles, and each art and music critic who did not support his aesthetic agenda was fired. Commitment to the Nazi ideology was more important than musical talent, thus loyal mediocrity was rewarded over skill. Composers and musicians were used as propaganda weapons of the Reich. They were composing marches and mass music to distract and entertain the population: countless compositions celebrated Hitler, Germany, and the glorious future of the Nazi Party. On a web page devoted exclusively to music and the holocaust, we read:

"On a broader social level, music was considered an important means of instilling 'German values', nationalism, and a sense of community. Countless musical organizations were established, musicians promoted, prizes awarded, and festivals staged with the intent that 'German' music reach into every home, school, and army barracks in the Reich." 19 
Music was not only present in marches and other propaganda events and celebrations. Soldiers on the front were encouraged to sing among themselves, and also the majority of soldiers' songbooks were published during the war years. There was a "music-corps" within the SS, and in some camps there were separate SS bands. Officers were organising musical events (such as cafes and cabarets) in many of the large ghettos for their own entertainment. Orchestras could also be found in concentration camps, where they were playing to amuse the Nazi guards.

"Music was also widely used as a means of torture: inmates were forced to play music while being beaten, or to sing while performing exhausting labour; music accompanied public hangings and executions, and was broadcast over loudspeakers during mass shootings." 20

Another example of political usage of music is the bifurcation of the Korean musical history that was carried out to reinforce the division between North Korea and South Korea. Following the arbitrary division of the country into a northern and southern sector, a unified tradition became fragmented. The musical policy reflected the dominant ideology in each sector: the communist concern for socialist realism in the north, and the capitalist interest in cultural traditionalism in the south. Due to such a bifurcation of musical history, the musical development on each side of the national divide followed its own orientation, spreading the belief that there are two separate musical heritages. Explaining the Korean musical tradition in one of his articles "Music across the DMZ", ${ }^{21}$ Keith Howard stated:t

"Until June 2004, huge loudspeakers erected at strategic intervals along the two-hundred-kilometre-length of the DMZ blasted propaganda at the opposing side. When tourists arrived at the truce village of Panmunjom, the speakers fell silent, then fired up again once the coaches departed. From the North, verbal abuse was juxtaposed with music, revolutionary songs, and songs telling of a land of plenty. The South aired a mixture dominated by American pop of the Michael Jackson kind, reflecting that American troops supplement South Korean forces, but hardly testament to the contemporary vibrancy of South Korean music." 22

Before the division, both Seoul and Pyongyang were centres of musical performance and education. But in the late 1940s many artists, among them also musicians, moved north due to their left-leaning beliefs. With these migrations several musical traditions, deriving from the south-western regions, were maintained in North Korea after the division, but only secretly among the migrants who were interested in the folk tradition. They did not fare well - many were purged, some executed. Alternatively, folk musicians from the north left due to the rise of the ideology of revolutionary art that emerged under the influence of Soviet socialist realism. In South Korea, national musical tradition was nurtured, and mainly classical Western music was imported. Meanwhile, pop music was controlled and censored at least until the 1990s. The Chinese regulated the artistic policy of North

16

Ibid., p. 12.

17

See ORT, "Music and the Holocaust", available at http://holocaustmusic.ort.org (accessed on May 14, 2016).

18

Ibid.

19

Ibid.
20

Ibid.

21

Keith Howard, "Music Across the DMZ", in John Morgan O'Connell, Salwa El-Shawan Castelo-Branco (eds.), Music and Conflict, University of Illinois Press, Urbana - Chicago - Springfield 2010, pp. 67-87.

22

Ibid., pp. 70-71. 
Korea. Korean tradition was suppressed as copies of Soviet and Chinese revolutionary songs were introduced and the emergence of proletarian art occurred.

"The Chinese program to modify instruments to accommodate Western modes and melodies was copied as a critical rehabilitation of traditional instrument began and folksongs were embraced as mass culture." 23

In copying other socialist states, musical training was institutionalised, popular songs gradually replaced the revolutionary songs and manufacturing of pop bands occurred.

A very interesting article by George Kent, titled "Unpeaceful Music", ${ }^{24}$ warns its readers, especially those who are inclined towards stressing the positive aspects of music, about the negative side of music - its dark side, its power to hurt and divide. He listed several examples of various usages of music that have a certain negative effect on listeners or a specific group of people. Kent started with describing the use of music as a repellent in cases where classical music was used outside some grocery shops in order to keep youngsters away. Other examples he listed are the national anthems themselves which may wake up feelings of nationalism, especially with their lyrics, or even emphasise militarism. The author also presented the dangers of insurrectionary music that might as well glorify evil or advocate violence. Hateful music is not hard to find either; for example, it might express racist beliefs or just harmful feelings towards the enemy in war. One of the most recent negative characteristics of music is its capitalist feature: the industrialisation and commodification of music which reinforces global inequities and also systematically trivialises music itself.

Jacques Attali, in his work Noise, described this phenomenon with the following words:

"Fetishized as a commodity, music is illustrative of the evolution of our entire society: deritualize a social form, repress an activity of the body, specialize its practice, sell it as a spectacle, generalize its consumption, then see to it that it is stockpiled until it loses its meaning. Today, music heralds - regardless of what the property mode of capital will be - the establishment of a society of repetition in which nothing will happen anymore." 25

The positive or negative effects of music on its users, its listeners, its performers or its environment depends on how it is being used, or more precisely, with what purpose it is being performed. But what makes music usable? Why can we use it as a tool or as a means to a certain end? Attali claims:

"All music, any organization of sounds is then a tool for the creation or consolidation of a community, of a totality." 26

So to say, music builds empathy, reinforces community, and establishes solidarity among people that share the same music. But how does music manage to do so?

Many studies where carried out to understand how engagement with music can affect life in a community, and affect its politics or social actions, and how it can contribute to the moral life of the culture. The article "Music, Mind, and Morality: Arousing the Body Politic" ${ }^{27}$ revealed some findings from the field of cognitive science that show us some ways in which music affects the brain, body, and behaviour of a human being.

Among the features that enhance the moral life of cultures, we might find that music's pulse gives to listeners a feeling of movement and helps coordinate them to move together - this is due to a reaction of the cerebellum (cerebellum 
part of the brain connected to movement). Music, with its pulse and melody, also stimulates sectors of the brain that are connected with the phenomenon of affection, and in this way it sets a common mood among listeners, and promotes a common feeling amongst the group. It can evoke a level of charged emotive bonding. It also affects the neural sites linked to the arousal of pleasure and displeasure. With all these influences taken into consideration, we can easily agree that music has the power of fostering the feeling of cohesion within a group of people, without which there is no ethical life.

At this point, let me introduce the notion of "community music", which is more than a notion. It is in fact an activity of a certain group of people. Lee Higgins, ${ }^{28}$ an advocate and performer of community music, explained that it is

“... a distinctive approach through which people are given opportunities to engage with active music making. " 29

The primary mode of its practice is carried out in the space that the author simply calls "the workshop". Through its structure, an open space that fosters the human desire of music making can be created. Higgins conceptualised the workshop through the Lyotardian notion of the "event", meaning that with the disruption of pre-existing frames or contexts it can provide an opportunity for the emergence of new forms and voices, and new genres of artistic discourse. Moreover, the Lyotardian notion of the event challenges us with its potential to transform. Higgins stressed that the commitment to openness is very important because it allows a genuine "welcome" to the potential participant. Higgins related "the welcome" to what Levinas described

" $\ldots$ as a relation to the infinite responsibility to the other person, a humanism of the other according to which being-for-the-other takes precedence over being-for-itself". ${ }^{30}$

This "welcome" is the ethical claim for the workshop-as-event; it is a call to the participant that releases the "ethical moment". Higgins explained that this type of ethical welcome is possible only if the facilitator of the workshop puts her ego into question, and by doing so establishes a relationship between herself and the participant that celebrates difference and encourages challenge through creative play. By doing so, in a way, the facilitator looks towards the

23

Ibid., p. 82.

24

George Kent, "Unpeaceful Music", in: Oliver Urbain (ed.), Music and Conflict Transformation. Harmonies and Dissonances in Geopolitics, I. B. Tauris - The Toda Institute for Global Peace and Policy Research, London - New York 2008, pp. 104-111.

25

Jacques Attali, Noise. The Political Economy of Music, University of Minnesota Press, Minneapolis - London 2009, p. 5.

26

Ibid., p. 6.

27

Philip Alperson, Noël Carroll, "Music, Mind and Morality: Arousing the Body Politic", Journal of Aesthetic Education 42 (1/2008), pp. 115. doi: http://doi.org/10.1353/jae.2008.0001.
28

In this article, the concept of "community music" is presented on the basis of the following Higgins' articles: Lee Higgins, "Community Music and the Welcome", International Journal of Community Music 1 (3/2008), pp. 391-400. doi: http://doi.org/10.1386/ ijcm.1.3.391_1.; "The Creative Music Workshop: Event, Facilitation, Gift", International Journal of Music Education 26 (4/2008), pp. 326-338. doi: http://doi.org/10.1177/0 255761408096074.; Lee Higgins, "One-toOne Encounters: Facilitators, Participants, and Friendship", Theory into Practice 51 (3/2012), pp. 159-166. doi: http://doi.org/10 $.1080 / 00405841.2012 .690297$

29

L. Higgins, "Community Music and the Welcome", p. 391.

30

Ibid., p. 392. 
impossible, which the author understands as a possibility that one did not and could not foresee:

"The impossible unconditional workshop-event is unachievable in terms of practical action, it is therefore yet to arrive, it is to come. Although it cannot be fully realized, its gesture directly affects the consequences of any facilitative process." 31

It makes the activity creative, open, inventive and challenging; moreover, it allows a welcoming space of diversity, equality of opportunity, social justice, tolerance and freedom. Higgins emphasised the awareness that the will for creation, and a disposition towards unconditional hospitality, generates constant tensions, and they arise because of the realities in which the workshop structure operates - these conditional limits immediately reduce any possibility of the unconditional promise to be realised. Higgins continued, saying:

"The embracing welcome attempts to resist self-closing unity within a structure that demands it. As a preparation for participants expected or unexpected, the unconditional hospitable workshop does not invade, occupy or colonize. Yet the conditional hospitable workshop is the only possible solution and as such has set boundaries, however faint they appear." 32

Higgins, from his understanding of the unconditional welcome, and the striving towards the impossible, introduced the idea of safety without safety that is the central practice, or even the method of the workshop as event.

"As a freedom from danger or risks, safety is always in the process of arriving: like the welcome it is to come. (...) the 'without' reminds us of our responsibility to the participants we work with." 33

He said that, in a way, this notion puts "danger" at the heart of the process, and that the success of the workshop is advanced through the possibility of failure, which is not understood as a mistake, but more as an important moment of learning. In this way, the musical invention can go beyond what one might be prepared for. By following this idea, we are always already welcoming the unexpected, the unknown. The usage of the term "invention" in Higgins" works comes from Derrida's explanation of the notion as

"... the coming of something new; something to come that is different from what has come before. It is a future desire that resists any sense of a fixed and static presence." 34

Higgins also stressed the importance of the role of the facilitator, the guide that leads the process, the one who "makes it easy" for the participants to involve in community music making. He said that

“... facilitation is concerned with encouraging open dialogue among different individuals with differing perspectives." 35

As stated before, the facilitator strives towards the unknown, the impossible, hospitality, and the unconditional. Higgins claimed:

"The unconditional is not impossible but the impossible. It is this desire for the impossible that haunts any real decision the music facilitator may make." ${ }^{36}$

In Higgins' method of the performance of community music, one might recognise how to put into practice the ethical gestures that were contemplated in the works of Emmanuel Levinas and Jacques Derrida. Noticeably, his practice joins responsibility, openness towards the other, hospitality, and the unconditional as the impossible towards which one should strive. Higgins managed to put them "in action" through the medium of music. In asking ourselves, again, why or how music allows us to do that we might also turn towards the philosopher that resonates at least some of the ideas of the two previ- 
ously mentioned ones. In the writings of Luce Irigaray, it is possible to find some moments specially dedicated to music, in which she connects it with the breath, voice, sound, silence, listening, openness, dialogue, hospitality, otherness, body, and space. She stated that music is the needed activity providing an environment for an intersubjective dialogue, since

“... music allows communication in an instant between people more easily. Of course, differences exist between the musical choices of diverse cultures but sharing them seems easier than going from the logic of one culture to that of another. We can listen to different music but not to different languages. To share a rhythm or a melody is easier and quicker than to share a linguistic universe. Above all music remains faithful to bodily and cosmic waves and vibrations which are universal, even if they are not equally discovered or awakened in all humans." 37

As a human activity, music emerges in the space of relationships, where intersubjective communication occurs and empathy and attentiveness among people are established while sharing the same music. With musical activities, musicking, or "community music" alike, people are able to learn straightforwardly how to listen to each other, communicate among themselves, accept the unknown other, and strive towards unconditional hospitality towards anyone. This is also a path to follow, consciously or unconsciously, in order to establish a more ethical world, where people would base their intersubjective relations on kindness and care.

\title{
Maja Bjelica \\ Glazbeno proizvedeni svijet \\ Mogućnosti rekompozicije i stvaranja ljudskog svijeta kroz djelatnost glazbe
}

\begin{abstract}
Sažetak
Ovaj rad nudi interdisciplinarni pogled i promišljanje međusobnih veza i odnosa između glazbe, ljudskog života i svijeta. S namjerom da se predstave mogući načini definiranja glazbe, razmatraju se dva pristupa: "glazbanje" (»musicking") i disjunktivna strategija razumijevanja glazbe, od kojih oba nude deskriptivni, no ne i vrednujući pogled. Nakon kratkog osvrta na glazbu kao sredstvo političke propagande ili sredstvo iz sfere masovne produkcije i konformizma, šire je predstavljeno drugo lice glazbe pomoću pojma "glazbe zajednice«, gdje težnja k nemogućem, kao bezuvjetna dobrodošlica, te beskonačna odgovornost prema drugome čine glazbu univerzalnom vježbom etičkih gestā, otvorenosti i prihvaćanja.
\end{abstract}

\section{Ključne riječi}

glazba, glazba i filozofija, definicija glazbe, glazba kao događaj, »glazbanje«, glazbeni susret, propagandna glazba, »glazba zajednice«, bezuvjetna dobrodošlica

31

Ibid., p. 393.

32

L. Higgins, "The Creative Music Workshop: Event, Facilitation, Gift”, pp. 328-329.

33

L. Higgins, "Community Music and the Welcome", pp. 394-395.

34

L. Higgins, "The Creative Music Workshop:

Event, Facilitation, Gift”, p. 330
35

L. Higgins, "One-to-One Encounters: Facilitators, Participants, and Friendship”, p. 165.

36

L. Higgins, "The Creative Music Workshop: Event, Facilitation, Gift", p. 334.

37

Luce Irigaray, "Before and Beyond Any Word", in: Luce Irigaray, Key Writings, Bloomsbury Publishing - Continuum, London - New York 2004, pp. 135-136. 


\title{
Maja Bjelica \\ Musikalisch menschengemachte Welt \\ Möglichkeiten einer Neuzusammensetzung und Schaffung der Menschenwelt durch die Aktivität von Musik
}

\begin{abstract}
Zusammenfassung
Dieser Artikel bietet einen interdisziplinären Bericht und eine Kritik an der Verbundenheit und den Beziehungen zwischen Musik, Menschenleben und Welt. Mit der Absicht, mögliche Wege der Definition von Musik zu präsentieren, werden zwei Ansätze untersucht: das „,Musicking“ (Musikpraxis) und die disjunktive Strategie des Musikverständnisses. Beide Ansätze bieten eine deskriptive und keine evaluative Sehweise. Nach einer kurzen Rückschau auf die Musik als Mittel der politischen Propaganda oder als Mittel aus der Sphäre der Massenproduktion und des Konformismus wurde die andere Seite der Musik in einer umfassenderen Art und Weise durch den Begriff der ,, Gemeinschaftsmusik" präsentiert, wo das Streben nach dem Unmöglichen als bedingungsloses Willkommen und die unendliche Verantwortung gegenüber dem anderen die Musik zu einer universellen Übung der ethischen Gesten, Offenheit und Akzeptanz machen.
\end{abstract}

\section{Schlüsselwörter}

Musik, Musik und Philosophie, Definition der Musik, Musik als Ereignis, „Musicking“ (Musikpraxis), musikalische Begegnung, Propagandamusik, „Gemeinschaftsmusik“, bedingungsloses Willkommen

\section{Maja Bjelica \\ Un monde humain musicalement construit \\ Possibilités pour recomposer et créer un monde humain à travers l'activité musicale}

\begin{abstract}
Résumé
Cet article propose une approche interdisciplinaire et une réflexion sur les interconnexions et les relations entre la musique, le monde humain et le monde. Dans l'intention de présenter les différentes manières possibles de définir la musique, deux approches seront examinées : l'activité musicale en tant que processus (" musicking ») et la stratégie disjonctive de compréhension de la musique. Ces deux approches privilégient l'explication descriptive et n'offrent pas de critères d'appréciations. Ainsi, après avoir brièvement déterminé la musique en tant que moyen politique de propagande ou en tant que sphère de production de masse et de conformisme, l'autre facette de la musique sera présentée plus largement à travers le concept de "musique communautaire ", où l'aspiration vers l'impossible en tant qu'accueil inconditionnel et responsabilité infinie des uns envers les autres font de la musique une pratique universelle des gestes éthiques, d'ouverture et d'acceptation.
\end{abstract}

\section{Mots-clés}

musique, musique et philosophie, définition de la musique, musique comme événement, activité musicale («musicking »), rencontre musicale, propagande musicale, « musique communautaire », accueil inconditionnel. 